\title{
PELATIHAN PEMBUATAN STIK DAN PILUS RUMPUT LAUT PADA KELOMPOK USAHA KELURAHAN KAMBAJAWA
}

\author{
Firat Meiyasa, Nurbety Tarigan, Gian Kirana Efruan, \\ Desy Asnath Sitaniapessy, Denisius Umbu Pati
}

\author{
Program Studi Teknologi Hasil Perikanan, Fakultas Sains dan Teknologi \\ Universitas Kristen Wira Wacana Sumba
}

\begin{abstract}
Abstrak
Kelompok usaha "Ceria 41", "Dahlia 28" dan "Sehati" merupakan kelompok usaha yang bergerak dalam menghasilkan produk olahan berbahan dasar pangan lokal. Kelompok usaha ini merupakan bagian dari ibu - ibu Pembinaan Kesejahteraan Keluarga (PKK) di Kelurahan Kambajawa, Sumba Timur, NTT. Tujuan dari kegiatan ini adalah melakukan pendampingan kepada masyarakat dengan cara memberikan informasi dan pengetahuan kepada kelompok usaha tentang pemanfaatan pangan lokal yang dapat dikembangkan menjadi oleh - oleh khas Sumba. Kegiatan ini terdiri dari tiga bagian, yaitu: workshop, praktek pembuatan stik dan pilus rumput laut, dan pendampingan serta pemasaran produk. Hasil dari pengabdian ini memberikan pengaruh positif pada ketiga kelompok tersebut, dimana produk yang dihasilkan dapat diterima oleh konsumen berdasarkan formulasi yang tepat dan juga desain kemasan yang menarik. Hal ini terlihat dari jumlah produk yang telah dipasarkan di berbagai lokasi seperti swalayan dan outlet yang ada di kota Waingapu Sumba Timur.
\end{abstract}

Kata Kunci: Rumput Laut, Stik, Pilus

\begin{abstract}
The business group of "Ceria 41", "Dahlia 28" and "Sehati" are business groups that are engaged in producing processed products made from local foods. The business group is part of the family welfare development (FWD) mothers in Kambajawa Village, East Sumba, NTT. The aim of the business group is to provide assistance to the local community by providing informations and knowledges to business groups with the topic using local food which can be developed into Sumba souvenirs unique. This activity consists of three parts, they are: workshops, practicing to make sticks and pillus seaweeds, assistance and products marketing. This activity resulted positive influences against three groups assistantships that the products produced can be accepted by consumers through applied the right formulation and attractive packaging design. This can be seen from the number of products which has marketed in the various locations such as supermarkets and outlets in the Waingapu city- East Sumba.
\end{abstract}

Keywords: Seaweed, Sticks, Pillus

Correspondence author: Firat Meiyasa, fmeiyasa@yahoo.com, Nusa Tenggara Timur, Indonesia

This work is licensed under a CC-BY-NC 


\section{PENDAHULUAN}

Rumput laut merupakan salah satu komoditas yang banyak dibudidaya di perairan Indonesia. Berdasarkan data Kementerian Kelautan dan Perikanan (KKP) produksi rumput laut Indonesia pada 2015 mencapai 10.335 .000 ton basah, 60\% dari capaian tersebut berasal dari NTT (Finance.detil.com, 2017). Sumba Timur termasuk salah satu daerah di NTT penghasil rumput laut yaitu sekitar 26.408 ton rumput laut basah atau 3.301 ton rumput laut kering. Diperkirakan produksi rumput laut akan meningkat hingga 570.656 ton rumput laut basah per tahun atau 57.066 ton rumput laut kering (Katadata.co.id, 2017).

Saat ini, prospek pengembangan budidaya rumput laut di Sumba Timur semakin meningkat. Meningkatnya produksi rumput laut di Sumba Timur, memberikan peluang usaha untuk pengembangan produk olahan berbahan dasar rumput laut. Diketahui saat ini, telah dilakukan pengembangan produk olahan berbahan dasar rumput laut seperti pembuatan stik dan pilus oleh masyarakat setempat, namun belum optimal dan tidak berjalan secara kontinyu. Hal ini disebabkan karena terbatasnya pengetahuan masyarakat terkait pengembangan produk olahan rumput laut. Selain itu, terbatasnya pengetahuan tentang bagaimana menciptakan suatu produk olahan yang dapat di terima oleh konsumen berdasarkan tingkat kesukaan seperti; penampakan, tekstur, rasa, warna dan aroma, tanpa menyampingkan nilai gizi dari produk itu sendiri. Untuk membuat stik dan pilus rumput laut yang dapat diterima dan disukai oleh konsumen perlu dilakukan formulasi yang tepat dan juga kemasan yang menarik dari produk tersebut. Sehingga produk yang dihasilkan dapat dipasarkan dikalangan masyarakat lokal dan juga dapat dijadikan sebagai oleh - oleh khas sumba.

Berdasarkan masalah diatas, perlu dilakukan salah satu kegiatan pengabdian masyarakat yang diharapkan dapat memberikan ilmu dan pengalaman bagi masyarakat. Secara umum tujuan dari kegiatan ini sdiharapkan masyarakat mampu menghasilkan produk olahan rumput laut dengan formulasi yang tepat sehingga dapat diterima dan disukai oleh konsumen nantinya. Secara khusus tujuan dilaksanakan kegiatan pengabdian kepada masyarakat ini adalah untuk melakukan pendampingan pada kelompok usaha Ceria 41, Dahlia 28 dan Sehati dalam mengoptimalisasi formulasi pembuatan stik dan pilus rumput laut. Memberikan informasi dan pengetahuan kepada masyarakat terkait dengan kewirausahaan dalam pemanfaatan bahan lokal. Selain itu produk yang dihasilkan diharapkan dapat dijadikan oleh - oleh khas Sumba.

\section{METODE PELAKSANAAN}

\section{Peserta}

Peserta kegiatan pengabdian kepada masyarakat terdiri dari 3 kelompok usaha yaitu kelompok Ceria 41, Dahlia 28 dan Sehati, Mahasiswa dan Dosen Prodi THP UNKRISWINA Sumba, Mahasiswa dan juga Kepala Bidang Pengolahan Hasil Perikanan, Kepala Kelurahan Kambajwa, Dinas Perikanan dan Kelautan Sumba Timur. Total peserta yang hadir berjumlah 50 orang.

\section{Waktu dan Tempat}

Kegiatan pengabdian kepada masyarakat inidilaksanakan pada tanggal $05 \mathrm{Mei}$ sampai dengan 07 Juni 2018, bertempat di Aula Kelurahan Kambajawa Sumba Timur. 
Dalam kegiatan pengabdian kepada masyarakat di wilayah kelurahan Kambajawa ini, kami melakukan observasidi lokasi PKM dan diskusi dengan Ibu Ratnawati F. L. Banepa, S.Pi., MAP sebagai Pembina dari ketiga kelompok usaha tersebut untuk membicarakan hal - hal teknis nanti selama kegiatan PKM berlangsung.

Tahapan selama kegiatan PKM

1. Tahap survei: pada tahap ini, kami melakukan survei lokasi PKM di kelompok usaha "Ceria 41", "Dahlia 28" dan "Sehati"

2. Tahap persiapan: pada tahap ini, dilakukan pembelian bahan dan alat yang digunakan untuk pembuatan stik dan pilus rumput laut. bahan yang digunakan berupa tepung tapioka, tepung terigu, rumput laut, telur, mentega, susu, gula, minyak goreng, minyak tanah, garam dan penyedap rasa. Peralatan yang digunakan adalah kompor, wajan, blender, baskom, alat pencetak stik, saringan minyak, dan plastik kemasan. Pada tahap ini, dipersiapkan juga desain label kemasan yang ditempel pada kemasan stik dan pilus rumput laut.

3. Tahap optimalisasi: pada tahap ini, dilakukan percobaan pembuatan stik dan pilus rumput laut. Tujuan dilakukan optimalisasi untuk mencari formulasi yang tepat sehingga produk yang dihasilkan dapat diterima oleh masyarakat.

4. Tahap pembuatan stik dan pilus rumput laut

a. Pembuatan stik rumput laut

Bubur rumput laut sebanyak $400 \mathrm{~g}$, gula pasir 5 sendok, mentega 7 sendok, telur 2 butir, keju $1 / 2$ balok, garam secukupnya dan baking soda di blender secara bersamaan hingga lembut. Kemudian, adonan tersebut dipindahkan ke dalam wadah lalu masukan tepung tapioka dan tepung terigu masing - masing $800 \mathrm{~g}$ dan $600 \mathrm{~g}$. setelah itu, uleri adonan hingga kalis benar lalu bagi kedalam beberapa bagian untuk di gilas dengan mol mie sampai pipih dengan ketebalan kurang lebih $0.5 \mathrm{~cm}$. Kemudian panaskan minyak goreng, lalu goreng stik dengan minyak panas sedang hingga berwarna coklat kekuningan, angkat dan ditiriskan.

b. Pembuatan pilus rumput laut

Sebanyak 200 g rumput laut di blender, tambahkan keju 1 balok, telur 3 butir, royco dan garam secukupnya lalu blender hingga homogen. Setelah itu, adonan dipindahkan ke dalam baskom lalu tambahkan tapioka $500 \mathrm{~g}$ campur hingga adonan kalis. Kemudian siapkan piring yang telah diberi minyak goreng yang cukup. Sebagian adonan diambil kemudian dipilin dengan tangan dan masukan ke dalam piring yang berisi minyak. Setelah itu, panaskan minyak goreng di dalam wajan lalu goreng adonan yang telah terbentuk hingga matang. Adonan yang matang siap didinginkan dan dikemas.

c. Adapun tahap - tahap kegiatan sebelum kegiatan PKM dilaksanakan. Tim dari Program Studi THP yaitu para dosen dan mahasiswa mempersiapkan segala sesuatu terkait dengan teknis pelaksanaan seperti; observasi lokasi PKM, diskusi dengan Ketua Pembina dari ketiga kelompok usaha tersebut, dan persiapan baik itu bahan baku yang dibutuhkan dalam pembuatan stik dan pilus rumput laut, persiapan snack maupun konsumsi selama kegiatan berlangsung. 


\section{HASIL DAN PEMBAHASAN}

\section{Workshop}

Pada hari pertama, kegiatan yang dilakukan adalah workshop seperti yang terlihat pada tabel 1. Hal ini bertujuan untuk memberikan materi pada kelompok usaha. Materi yang disampaikan pada kegiatan workshop yaitu; Manfaat rumput laut dalam pembuatan "stik dan pilus" dan teknologi pengemasan serta strategi pemasaran; Pengolahan stik dan pilus keju berbahan dasar rumput laut; dan Peluang usaha dan analisis usaha. Pada sesi kegiatan workshop dilakukan dengan cara diskusi antara pemateri dan kelompok usaha.

Tabel 1 Jadwal Workshop pada 12 Mei 2018

\begin{tabular}{|c|c|}
\hline Jam / Waktu & Acara \\
\hline $07.00-08.45$ & Persiapan \\
\hline $09.00-09.10$ & Pembukaan dan Doa \\
\hline $09.10-09.55$ & $\begin{array}{l}\text { Kata sambutan: } \\
\text { 1. Ketua Panitia } \\
\text { 2. Plt. Kaprogdi THP } \\
\text { 3. Lurah }\end{array}$ \\
\hline \multirow[t]{3}{*}{$10.00-12.10$} & $\begin{array}{l}\text { Workshop dan diskusi: } \\
\text { "Pemberdayaan Kelompok Usaha "Ceria 41", "Dahlia 28" } \\
\text { dan Sehati dalam Pembuatan Stik dan Pilus Berbahan Dasar } \\
\text { Rumput Laut Kelurahan Kambajawa" }\end{array}$ \\
\hline & $\begin{array}{l}\text { Pemateri } 1 \text { : Firat Meiyasa, SP., M.Si } \\
\text { Materi: "Manfaat Rumput Laut dalam Pembuatan "Stik dan } \\
\text { Pilus" dan Teknologi Pengemasan Serta Strategi Pemasaran" }\end{array}$ \\
\hline & $\begin{array}{l}\text { Pemateri } 2 \text { : Nurbety Tarigan. S.Pi., M.Si } \\
\text { Materi: "Peluang Usaha dan Analisis Usaha" }\end{array}$ \\
\hline $13.00-13.30$ & Istirahat dan makan siang \\
\hline $13.30-14.30$ & $\begin{array}{l}\text { Pemateri 3: Ratnawati F. L. Banepa, S.Pi. MAP } \\
\text { Materi: "Pengolahan Stik dan Pilus Keju Berbahan Dasar } \\
\text { Rumput Laut" }\end{array}$ \\
\hline $14.30-17.00$ & Praktek dan Diskusi \\
\hline $17.00-17.30$ & Snack dan Doa Penutup \\
\hline $\begin{array}{l}\text { Total lama } \\
\text { kegiatan workshop }\end{array}$ & 10,30 jam \\
\hline
\end{tabular}

Pada sesi materi pertama, kelompok usaha diberi materi mengenai potensi rumput laut, manfaat rumput laut terhadap kesehatan, model kemasan yang digunakan, manfaat dari pengemasan, pelabelan dan isi label kemasan, contoh - contoh kemasan dan labelnya dan strategi pemasaran produk olahan.

Pada sesi kedua, kelompok usaha diberikan materi mengenai teknik - teknik pengolahan yang baik dan benar, proses pembuatan stik dan pilus rumput laut yang sesuai dengan percobaan yang telah dilakukan.

Pada sesi ketiga, kelompok usaha diberikan materi mengenai peluang usaha dan analisis usaha. Kelompok usaha diberikan pemaparan terkait dengan penentuan jumlah 
produksi dan biaya produksi selama kegiatan berlangsung. Kemudian, dipaparkan juga perhitungan untung atau rugi yang bisa di prediksi selama kegiatan.

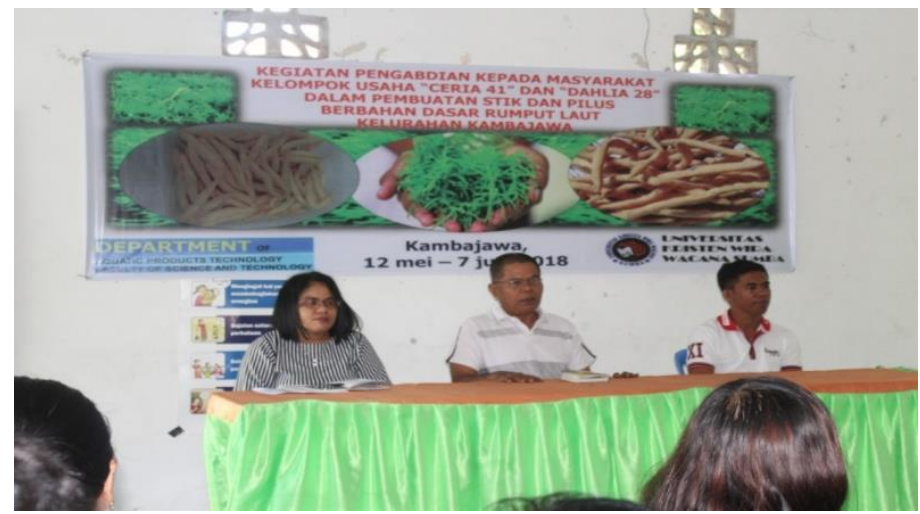

Gambar 1 Acara Kegiatan Workshop PKM

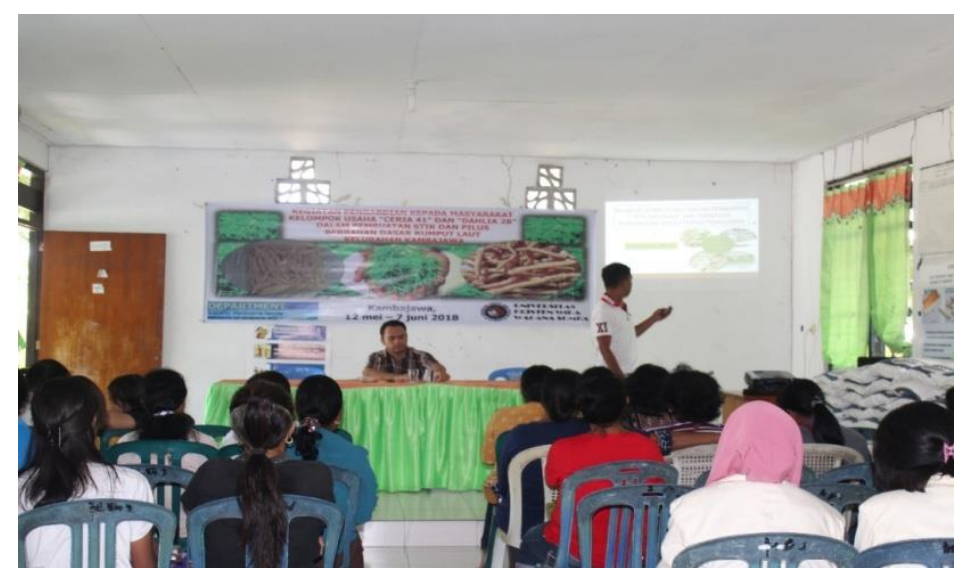

Gambar 2 Pemateri pertama oleh: Pak Firat Meiyasa, S.P., M.Si

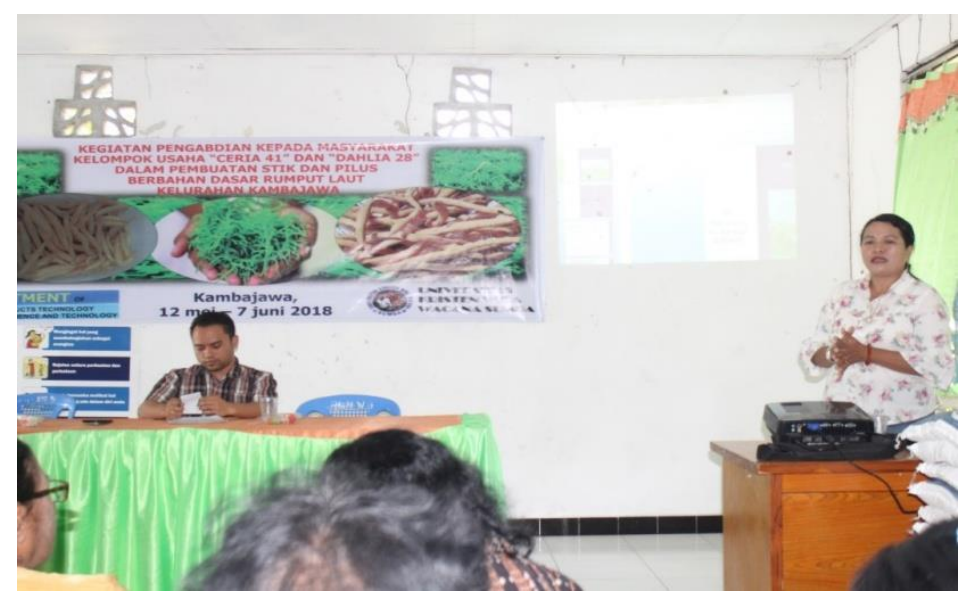

Gambar 3 Pemateri kedua oleh: Ibu Ratnawati F. L. Banepa, S.Pi., MAP 


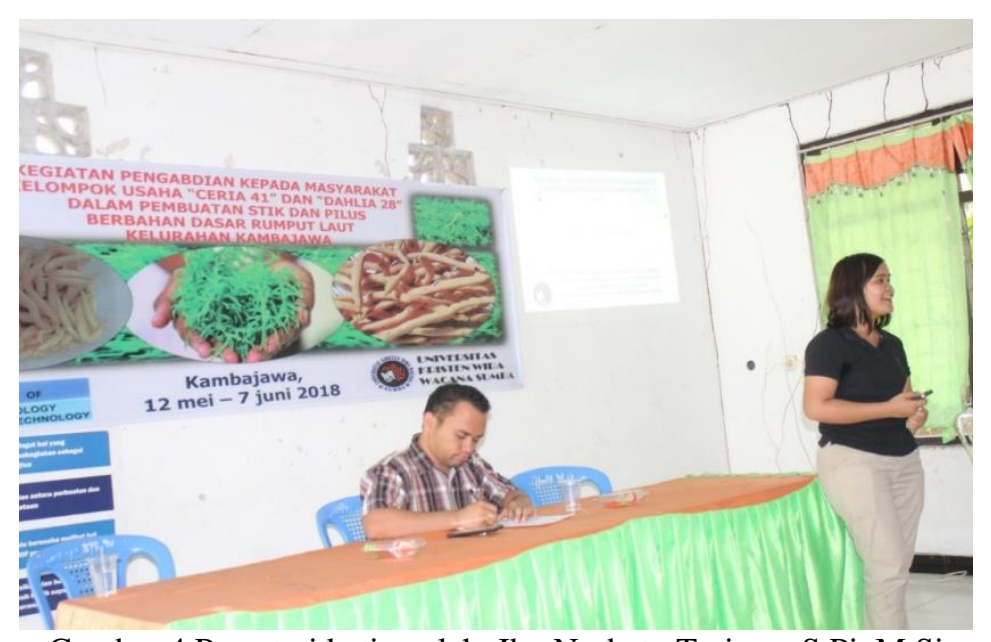

Gambar 4 Pemateri ketiga oleh: Ibu Nurbety Tarigan, S.Pi.,M.Si

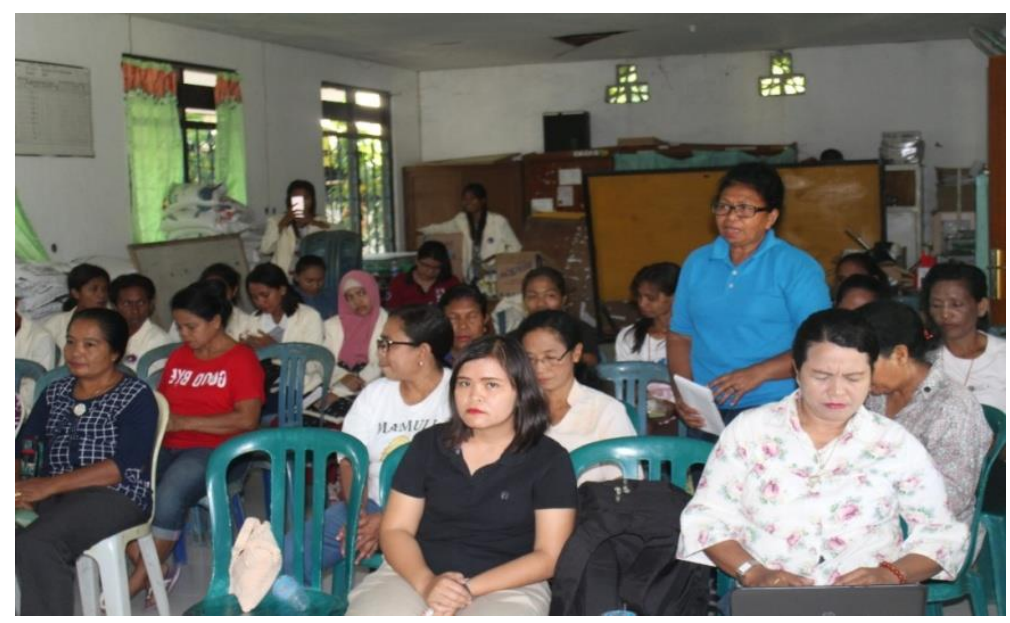

Gambar 5 Sesi diskusi selama kegiatan workshop

\section{Praktek pembuatan stik dan pilus berbahan dasar rumput laut}

Pada sesi kegiatan ini, dilakukan praktek langsung pembuatan stik dan pilus berbahan dasar rumput laut. Kegiatan ini dihadiri oleh ketiga kelompok yakni kelompok "Ceria 41", "Dahlia 28" dan "Sehati". Kegiatan ini didampingin oleh dosen Prodi THP Universitas Kristen Wirawacana Sumba yang bekerjasama dengan Dinas Perikanan Sumba Timur.

Pada kegiatan ini, peserta dilatih untuk mengetahui formulasi yang tepat dan teknik pembuatan stik dan pilus berbahan dasar rumput laut yang baik ditinjau dari rasa, warna, tekstur, dan penampakan dari produk tersebut, serta kemasan yang dapat diterima oleh konsumen. 


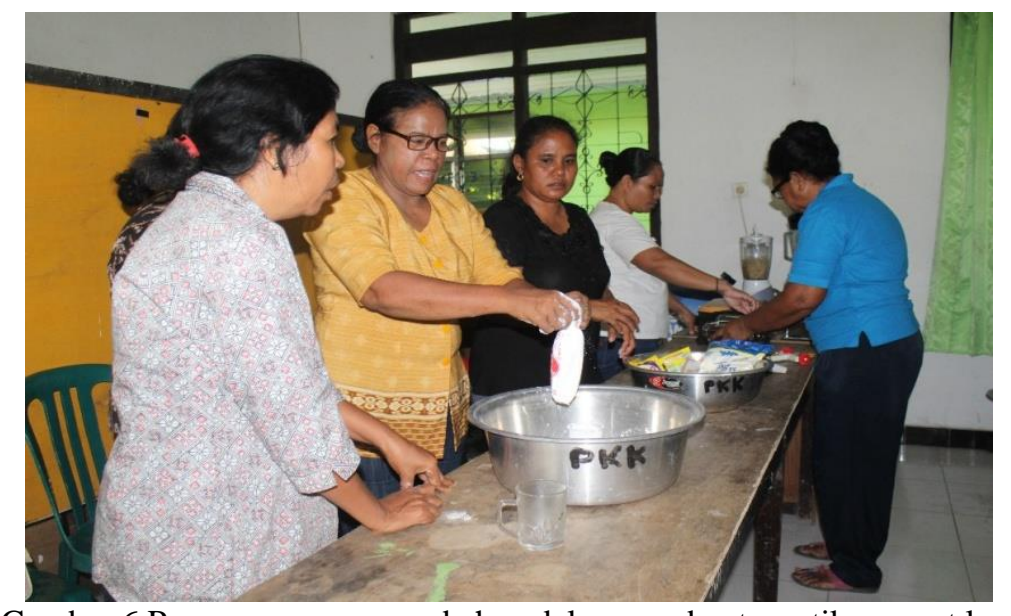

Gambar 6 Proses pencampuran bahan dalam pembuatan stik rumput laut

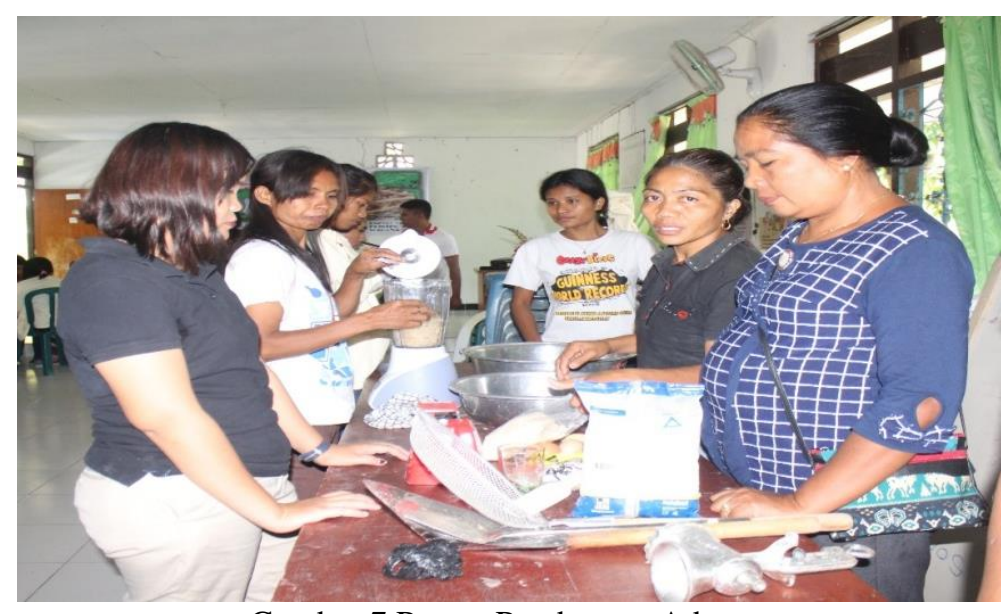

Gambar 7 Proses Pembuatan Adonan

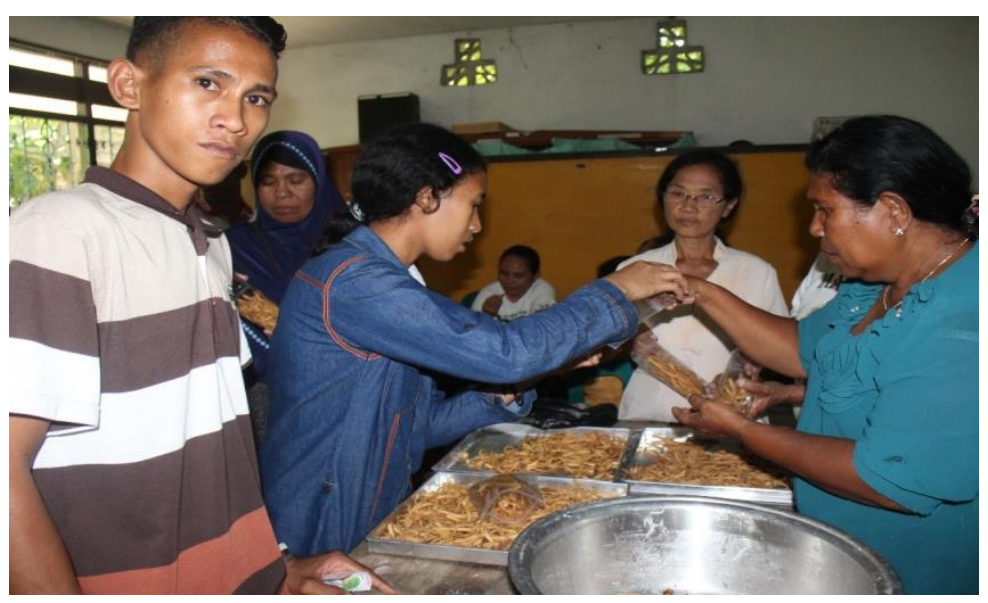

Gambar 8. Hasil Penggorengan Stik Rumput Laut 


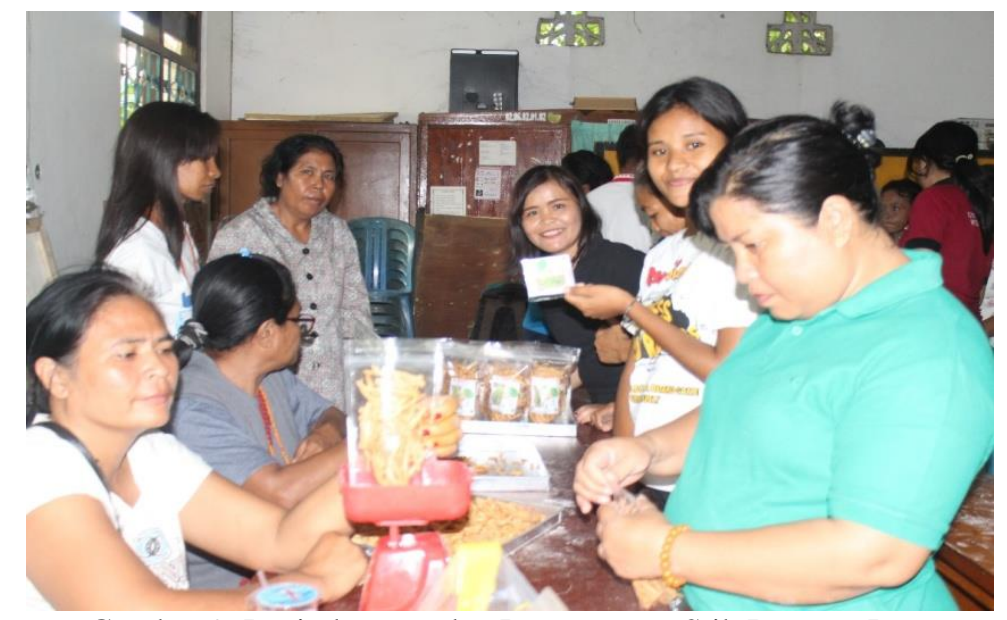

Gambar 9. Penimbangan dan Pengemasan Stik Rumput Laut

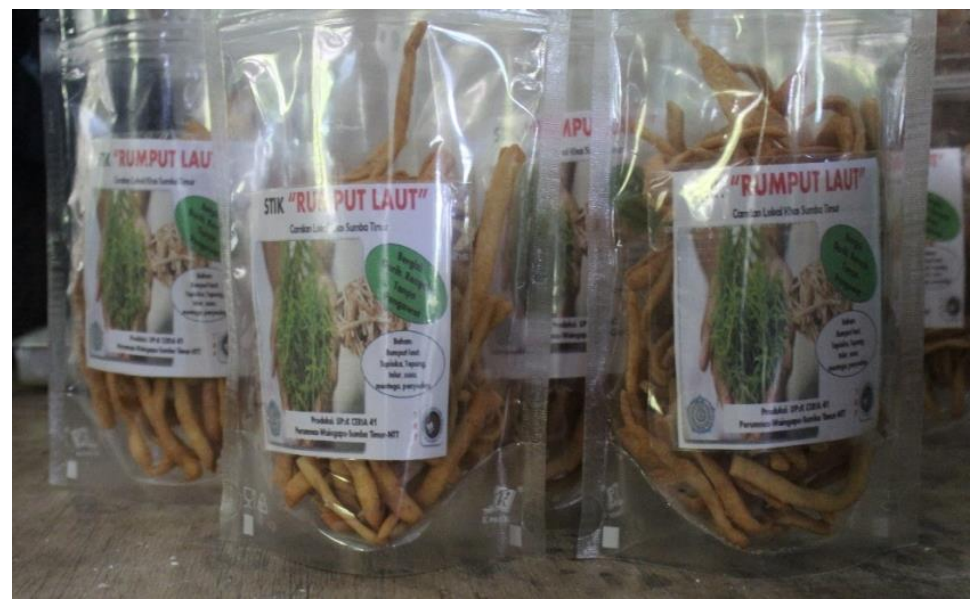

Gambar 10. Produk Stik Rumput Laut yang sudah dikemas

\section{Pendampingan dan Pemasaran}

Kegiatan pendampingan dan pemasaran dilakukan setelah kegiatan workshop dan praktek pembuatan stik dan pilus rumput laut. Pendampingan ini dilakukan sembilan kali selama kegiatan pengabdian berlangsung. Dalam tahap kegiatan ini dilakukan pendampingan di setiap kelompok usaha baik kelompok Ceria 41", "Dahlia 28" maupun "Sehati". Pada setiap kelompok masih tetap dilakukan pendampingan dalam proses pembuatan stik dan pilus rumput laut. Tujuan dari kegiatan pendampingan ini adalah untuk meminimalisir kegagalan dalam proses produksi produk tersebut. Selain itu, dalam kegiatan pendampingan ini juga bertujuan untuk menjaga konsistensi produk dari segi warna, rasa, tekstur, dan penampakan produk. Hasil dari setiap pendampingan, produk yang dihasilkan kemudian dipasarkan. Target pemasaran produk ini adalah di swalayan, toko/ outlet, kafe maupun hotel yang ada di Kota Waingapu.

\section{SIMPULAN}

Kegiatan pengabdian kepada masyarakat (PKM) memberikan manfaat kepada kelompok usaha baik kelompok Ceria 41", "Dahlia 28" maupun "Sehati" berupa informasi baru tentang pembuatan stik dan pilus rumput laut, teknik desain kemasan, dan pemasaran produk yang dihasilkan. Selain itu, hasil PKM ini sudah dijadikan oleh oleh khas Sumba. 


\section{DAFTAR PUSTAKA}

Katadata.co.id. (2017). https://www.google.com/search?safe=strict\&source=hp\&ei=-STXJSxGZS0vwTqkawCA\&q=Diperkirakan+produksi+rumput+laut+akan+meni ngkat+hingga+570.656+ton+rumput+laut+basah+per+tahun+atau+57.066+ton+r umput+laut+keringput+laut+kering.

Finance.detik.com.

(2016). https://www.google.com/search?safe=strict\&ei=ATCTXKCLOIj8vAS64oWQB $\mathrm{w} \& \mathrm{q}=$ Berdasarkan+data+Kementerian+Kelautan+dan+Perikanan+\%28KKP\%2 9+produksi+rumput+laut+Indonesia+pada+2015+mencapai+10.335.000+ton+ba sah\&oq=Berdasarkan+data+Kementerian+Kelautan+dan+Perikanan+\%28KKP $\% 29+$ produksi+rumput+laut+Indonesia+pada+2015+mencapai+10.335.000+ton tbasahab. 